\title{
A Survey of the Use of English Vocabulary Mnemonic Strategies by Non-English Majors
}

\author{
Yiying Wang \\ Shanxi Normal University, Shanxi, China
}

\begin{abstract}
Vocabulary can be regarded as an absolutely necessary part of language learning. Since the late 1970s, there have been a great lot of researches by native English learners on English vocabulary mnemonic strategies. Recently, many experts who are in the field of second language acquisition have been studying and researching all kinds of mnemonic strategies. But few researches focus on the study of the use of mnemonic strategies by non-English majors. Therefore, this investigation study focuses on the use of mnemonic strategies and the relevance between the strategies and the vocabulary grades. This study will investigate some subjects by means of a questionnaire survey to collect explicit data. And by analyzing the relevance between the strategies and the grades, this study can provide some effective suggestions about vocabulary learning. According to the research, the strategy used most frequently is repetition strategy. Because of the influence of traditional language learning theory, most students choose to use repetition strategy. And we can get that students should try more strategies to memorize words and teachers also should introduce more strategies to students.
\end{abstract}

Index Terms - mnemonic strategies, non-English majors, vocabulary acquisition

\section{INTRODUCTION}

Vocabulary plays an elementary role in second language learning and many scholars gradually recognize the importance of vocabulary acquisition and have been devoting to researching it.

\section{A. Background of Research}

Recently, many experts and scholars give explicit descriptions and detailed researches to English vocabulary mnemonic strategies. Nation (1990) and other experts discusses the various mnemonic strategies. Luppescu and Day (1993) studies the relationship between reading, dictionary usage and words memory. In addition, many scholars have discussed the effects of various mnemonic strategies, most of whom support the repetition and keyword methods. But few researches focus on the use of English vocabulary mnemonic strategies by non-English majors.

\section{B. Purpose of Research}

Enlarging vocabulary is the main task of English learning for non-English majors. While, during the process of learning English, the main problem is ineffective vocabulary memorization and remembering words occupies most of the time. Thus, this study is to seek the English vocabulary mnemonic strategies used by non-English majors, and analyse the correlation between these strategies and vocabulary grades so that the effective suggestions can be provided for non-English learners to help them learn English more happily, easily and efficiently. And this investigation study chooses fifty non-English majors as subjects to take part in.

\section{THEORY}

There are many scholars at home and abroad who have studied the mnemonic strategies. Mnemonic strategies can be related to the information processing system of human beings.

\section{A. Memory}

Memory researches have had a long history in psychology. German psychologist, in 1885, Ebbinghaus who is the first export to research the relationship between memory and forgetting uses nonsense syllables to do an early scientific research on memory. Carroll (2000) refers to the information processing system, which consists of three structural components: sensory memory, working memory and permanent memory. And according to Baddeley's view (2003), working memory is important for a wide range of complex cognitive activities. And he puts forward a forth subsystem, episodic buffer on basis of the former theories.

\section{B. Mnemonic Strategies}

As for mnemonic strategies, Oxford (1990) points out that mnemonic strategies are the methods of linking new information to existing knowledge.

There are many experts who have classified mnemonic strategies into various groups. Craik and Lockhart (1975) proposes level-of-processing mode which provides a theory for the classification of memory strategies. Then according 
to this theory, Lv wenpeng (2001) puts forward shallow coding method which includes pronunciation, repetition, homonyms and familiar words, etc, and deep coding method which includes association, context and flexible, etc.

Schimitt (1997) divides mnemonic strategies into nine types: illustration method, semantic association method, experience association method, semantic chart, key words method, grouping, reading aloud repeatedly, image imagination, semantic network, etc.

Meanwhile, many scholars have investigated mnemonic strategies. Ma Guanghui (1997) chooses 12 non-English majors as subjects and her investigation shows that there are significant differences between the students with high scores and the students with low scores in mechanical strategy. Lawson \& Hogben (1998) groups these strategies into four types and the report of their investigation indicates that the keyword-trained students have a significant advantage. Wang Wenyu (1998) has an investigation, according to which he concludes that planning strategy and flexible strategy have the greatest correlation with the students' vocabulary scores. Wu Jianmin and Yao Meilin (2000) choose 143 junior school students as subjects and they concludes that the most of the students use planning strategy and repetition strategy frequently.

This study adopts eight variables: planning strategy, vocabulary chart strategy, repetition strategy, association strategy, vocabulary construction strategy, context strategy, flexible strategy and key words strategy.

Wen qiufang (1996), O’Malley and Chamot (1990), Ronald and McCarthy (1990) and Atkinson and Shiffrin (1968) have introduced planning strategy, association strategy, context strategy and key word strategy.

In brief, association strategy is a learning strategy that associates with related things, or in the direction of special guidance, sets up a constant connection between people and knowledge, so that to deepen the memory of the learners, and associates knowledge. Therefore, the memory of the words by association is to find the commonness between the new words and the words that have been learned in the way of association under the guidance of the teachers and to deepen the memory of the new words from sound, form, and meaning. This will not only help the students learn new words, but also review the old words at the same time so that students can remember words more firmly.

And word construction strategy is used to help students connect new formation with the formation they have known under the word formation rules, so as to achieve the goal of long-term memory. The development of modern English vocabulary is mainly based on word formation. The affixes and compound methods account for a large proportion. The root is the basis of derivatives, and affixes can play a decisive role in the lexical meaning and grammatical attributes of derived words. It can be said that affixes and roots are the most important keys to expand the vocabulary. Apparently, word construction analysis strategy is helpful for students to remember words.

Flexible strategy is to use the newly learned words consciously in conversation and writing, and to do vocabulary exercises with these new words, or to talk about these words with others in order to deepen the memory. At present, this is a memory strategy universally recognized by scholars. They think using new words consciously in conversation and writing can deepen their memory and on the other hand deepen their understanding of the meanings and usages of words. Therefore, the flexible strategy is a way to understand to memorize, rather than to memorize mechanically.

\section{SURVEY PROCEDURE}

The procedure of this survey includes three parts: subjects, instrument, and data collection and analysis of results.

\section{A. Research Subject}

There are fifty non-English majors taking part in this study. Their average age is 21.7. They have been learning English for seven or eight years, so they have formed a set of stable and unique way of remembering words. That is the reason why they are chosen as research subjects.

\section{B. Research Instrument}

The research instruments include a questionnaire which is designed to describe above mnemonic strategies and the students' different situations and a vocabulary test. The contents of questionnaires include two parts: personal data and the strategies. The first part takes the form of filling in the blanks and the second part adopts the form of choice. In that part, " 1 " means "It's completely out of my condition"; "2" is "Basically it is not in my case"; " 3 " is "Sometimes it is in line with my condition, sometimes it dose not agree with my situation"; "4" means "Basically it conforms to my situation"; and "5" means "Completely it is in line with my situation". The questions of the questionnaire are based on the related literature and observation in the process of learning.

The vocabulary test is to examine students' vocabulary and the mastery degree of vocabulary. The test asks students to translate or paraphrase according to the given English words. Nation (1990) believes that this method had many advantages. It is not only convenient, but what it requires is exactly what they listen to, read, speak and write in normal time. These are the reasons why this study chooses this method. There are forty words in this test and all of them are from those words that non-English major students must master according to College English Syllabus, which are suitable for this test.

\section{Data Collection and Analysis of Result}

Fifty students finish the questionnaire and the test. Then, the SPSS is used to analyze data. This study involves eight 
variables, among which seven are composed of two or more than two questionnaires, and the internal unity reached statistical requirements. Tab.I shows the names of these variables, number of items and contents of questionnaire.

\begin{tabular}{|c|c|}
\hline $\begin{array}{l}\text { Names } \\
\text { numbers }\end{array}$ & $\begin{array}{l}\text { TABLE I. } \\
\text { DESCRIPTION OF VARIABLES } \\
\text { The Simple Description }\end{array}$ \\
\hline Planning strategy(2) & $\begin{array}{l}\text { Plan and manage the whole process of memory, such as choosing the words to memorize, choosing the } \\
\text { appropriate memory methods, and reviewing regularly. }\end{array}$ \\
\hline Vocabulary chart strategy(3) & Use self-made word list to help memorize words. \\
\hline Repetition strategy(3) & Read and write again and again. \\
\hline Association strategy(3) & $\begin{array}{l}\text { Help to memorize new words through associative words, such as associative homophones, synonyms and } \\
\text { antonyms. }\end{array}$ \\
\hline $\begin{array}{l}\text { Word construction analysis } \\
\text { strategy(2) }\end{array}$ & Memorize words by using phonetics and lexicology knowledge, such as analyzing roots, affixes, etc. \\
\hline Context Strategy(2) & Use context to memorize words. \\
\hline Flexible strategy $(2)$ & Use words that have just been learned in conversation and writing to deepen memory \\
\hline Key words strategy(1) & $\begin{array}{l}\text { Select a key word from mother tongue that is similar to the target word that will be learned, and establish a } \\
\text { close connection between the target word and the key word, so that the target word is immediately } \\
\text { associated with the key word when the learner hears or sees it. }\end{array}$ \\
\hline
\end{tabular}

1. The use of vocabulary mnemonic strategies

In the process of memorizing words, students adopt a series of methods to enhance memory. (see Tab II).

TABLE II.

The Mean And Standard Deviation Of Memory Strategies

\begin{tabular}{l|l|l} 
Strategy & Mean & Standard deviation \\
\hline Planning strategy & 2.71 & 0.57 \\
\hline Vocabulary chart strategy & 2.54 & 0.73 \\
\hline $\begin{array}{l}\text { Repetition } \\
\text { strategy }\end{array}$ & 3.69 & 0.63 \\
\hline Association strategy & 3.22 & 0.65 \\
\hline $\begin{array}{l}\text { Word construction analysis } \\
\text { strategy }\end{array}$ & 3.15 & 0.69 \\
\hline Context Strategy & 2.81 & 0.77 \\
\hline Flexible strategy & 2.75 & 0.72 \\
\hline Key words strategy & 2.86 & 0.74
\end{tabular}

The most frequently used strategy is repetition strategy, followed by association strategy and word construction analysis strategy, and the lowest is vocabulary chart strategy, planning strategy, context strategy, key words strategy and flexible strategy.

Some western scholars advocate learning words naturally through extensive reading, and do not encourage students to recite words. However, the students generally used the mechanical memory method of repetition strategy. There are two reasons: first, because these students are influenced by the traditional Chinese language learning theory and practice. Recitation has been a widely used method of learning language since ancient time. Recitation still plays an important role in modern Chinese language teaching, and it affects the foreign language teaching. When learning a foreign language, reciting words, reciting sentences and reciting texts are great learning tasks for students, and which are also teachers' important assessment of the students' knowledge. Therefore, repeating is the most commonly used method for students. Second, these students are restricted by the specific learning environment, and it is difficult to acquire words naturally. It is found that in order to remember a new word successfully, the students have to meet it at least seven times. While, other scholars point out that students can remember a new word naturally after meeting it sixteen times. It is obvious that in order to acquire a new word naturally, there must be a learning environment that can provide opportunities to do extensive reading, so that students can often meet the same word in a certain amount of times and then they can remember it naturally. However, at present, there is no environment to expose to English extensively in China. And there are not so many English reading materials. Most students, especially non-English majors, do not have the conditions to read all kinds of English books and periodicals at all. For these students, English textbooks are almost the only materials they read. Therefore, it is not suitable for Chinese non-English majors to learn a lot of words by reading and listening more and more naturally. Most of them take the "recite" to memorize new words when they encounter them in the textbook.

The other two strategies are association strategy and word construction analysis strategy. The use of these two strategies is closely related to college English teaching. At present, all kinds of college English textbooks put the knowledge of word construction and the contrast of synonyms and antonyms into after-school exercises. Many college English teachers also make the distinctions between various synonyms and antonyms the key points of the vocabulary explanation, and impart various word formation knowledge in the teaching process. Therefore, classroom teaching has a certain impact on vocabulary mnemonic strategies of non-English majors.

The survey also shows that non-English majors are still more limited in memorizing words, and lack systematic 
planning and management of their vocabulary learning. In addition, students are less likely to use flexible strategies in vocabulary memory because the main channel for students' English learning is to read the contents of the textbook. As for the key word strategy, it should be the relatively common strategy for non-English majors, because it has close connection with their mother tongue. While the most English teachers do not advocate their students to use this strategy because they are afraid that by using this way, their students cannot acquire English vocabulary correctly and directly and even misunderstand them.

2. Correlation between Memory Strategies and Vocabulary Test Scores

The grades of vocabulary of students are quite different (see Tab III).

\begin{tabular}{l|l|l|l|l|l|l|l|l} 
TABLE III. \\
$\begin{array}{l}\text { Fractional } \\
\text { segment }\end{array}$ & $30-40$ & $40-50$ & $50-60$ & $60-70$ & $70-80$ & $80-90$ & $90-100$ \\
\hline $\begin{array}{l}\text { Number } \\
\text { people }\end{array}$ & of & 2 & 6 & 3 & 14 & 13 & 11 & 1
\end{tabular}

In order to understand the relationship between their performance in test and the strategies they use, the correlation coefficient between each strategy and test results is calculated. The strategies with significant correlation are planning strategy, flexible strategy, word construction analysis strategy and vocabulary chart strategy (see Tab IV).

TABLE IV.

THE Correlation COEFFICIENT OF MNEMONIC STRATEGY AND VOCABULARY GRADES

\begin{tabular}{l|l|l|l|l} 
& \multicolumn{2}{|c}{ AND VOCABULARY GRADES } & Vocabulary chart strategy \\
Mnemonic & Flexible strategy & Planning strategy & $\begin{array}{l}\text { Word construction } \\
\text { analysis strategy }\end{array}$ & Vorat \\
\hline $\begin{array}{l}\text { Vocabulary } \\
\text { grades }\end{array}$ & 0.63 & 0.69 & 0.55 & 0.41
\end{tabular}

Repetition strategy, association strategy, key words strategy and context strategy don't show significant correlation. It is obvious that flexible strategy and planning strategy have a certain influence on the memory effect of words. The students use flexible strategy, which means they use new words consciously in conversation and writing. On the one hand, using flexible strategy can help consolidate these new words, and on the other hand, it can also deepen the comprehension of the meanings and usages of words. This is not a mechanical consolidation of memory, but a deepening of memory on the basis of understanding. So memory effect is much better. The planning strategy in this survey includes the choice of words, the selection of memory methods, the test of the words which have been learned and the periodic review. To a large extent, the use of management methods determines the effectiveness of the learning methods. Therefore, although the choice of memory method and self test can not directly affect the process of memory, it has great effect on memory.

\section{SUGGESTIONS ON THE IMPROVEMENT OF THE ABILITY TO MEMORIZE ENGLISH VOCABULARY}

The study shows that Chinese students adopt a series of strategies in the process of English vocabulary acquisition, such as planning strategy, vocabulary chart strategy, repetition strategy, association strategy, context strategy and flexible strategy etc. There is a significant correlation between these students' vocabulary test scores and the adopted mnemonic strategies. Among them, the correlation of planning strategy and flexible strategy are the most significant. Although western scholars strongly advocate the theory of natural acquisition, this study shows that most Chinese students have adopted repetition strategy in learning words, which is caused by the Chinese language learning habit. Therefore, the theory of natural acquisition is not suitable for Chinese students.

In addition, the findings of this survey also have implications for vocabulary memorizing. They point out that adopting a series of mnemonic methods is very helpful for memory effect. Students should first plan and manage their own memory process consciously. Second, in the process of memorizing words, they need to use various methods to complement each other for the best results. After remembering the words, students should use and practice them more and more and review regularly. And the task of remembering words can not be completely given to students, so that the vocabulary memory always stays at a spontaneous stage. On the contrary, teachers should help students enlarge vocabulary and improve their English by teaching the knowledge of lexicology and creating more opportunities for students to practice and use words.

\section{CONCLUSION}

Based on the previous study, some conclusion can be drawn. Through questionnaire, it is concluded that the repetition strategy is used generally. And by analyzing the correlation between mnemonic strategies and vocabulary grades, the planning strategy and flexible have a certain influence on the vocabulary mnemonic strategies. Every strategy has advantages and disadvantages, and all strategies are suitable for students. And as for the study, there are some merits and defects, which will be illustrated. 


\section{A. Implication}

In the traditional pattern, the main task of teachers is to teach the knowledge of language which is required by syllabus in a boring way and the main task of students is to accept the knowledge of language passively. Therefore, most students feel that learning English is very boring and tiring. Recently, the Ministry of Education has decided to implement the education of all-around development. Under the modern educational system, the old way is obsolete. Students should use strategies to help manage their study, and try various ways to improve their memory efficiency. On the other hand, teachers ought to realize the importance of mnemonic strategies on students' vocabulary memorizing. Because some students don't know other strategies apart from repetition strategy, teachers can provide various mnemonic strategies to help them remember vocabulary happily and easily and to arouse students' enthusiasm. Teachers also can encourage them to take part in learning actively. In addition, teachers should have the ability to combine the cultivation of autonomous learning with the current teaching tasks. In this way, we not only cultivate students' autonomous learning ability, but improve the learning efficiency.

\section{B. Limitations and Suggestions}

Although the questionnaire is on the basis of an elaborate design and hard work, there are still some mistakes and shortcomings to be improved in the future study.

First, the number of respondents is only fifty, it is not comprehensive enough. That is to say, this figure cannot be representative of the whole non-English majors. Second, the data from the questionnaire just respond to the feelings of the respondents at that moment, and it cannot guarantee the authentic use of mnemonic strategies in the process of learning in the normal time. At that time, they may believe that they used those strategies. But they may not use them in their real process of vocabulary memorizing. This factor may influence the reliability and validity of the test results. Therefore, there are some improvements to be made in the future study.

And as for the suggestions, because there are limitations and disadvantages in this study, recommendation and proposals should be taken into consideration. In the first place, the interview method and case study method should be added, from which the data got is closer to the actual and authentic situation, so that the reliability and validity of the research can be guaranteed. Second, the number of the participants should be enlarged. In the future study, there should be more participants from different majors, different grades, different universities. Thus, the data can be more comprehensive and representative.

\section{APPENDIX A}

非英语专业学生词汇记忆策略调查问卷

1. 完全不符合我的情况

2. 基本不符合我的情况

3. 有时符合我的情况, 有时不符合我的情况

4. 基本符合我的情况

5. 完全符合我的情况

一、个人资料

姓名:

二、调查问卷

1. 对于要记忆的单词会制定计划, 比如记忆单词的时间, 记忆单词的数量等。

2. 将记忆的单词记在袖珍笔记本上随身携带, 有时间就记。

3. 通过背诵词汇表来记忆单词。

4. 制作单词卡片或单词表来记单词。

5. 利用英汉对照的单词表来记忆单词。

6. 通过反复拼写朗读的方式记忆单词。

7. 通过一遍遍反复抄写来记忆单词。

8. 我反复复习与回想学过的单词。

9. 记单词时，我会联想到其同义词、反义词、同音词、同形来组合记。

10. 我记单词时将其不同语法形式的变体联系起来组合在一起。如联想到单词的名词、动词、形容词、副词 等 形式。

11. 我记单词时联想所反映的情景或画面。 1.2.3.4.5

12. 我记单词时通过构词法（如前缀、后缀、词根等）来记忆单词。

13. 将拼写与读音结合起来分析与记忆单词。

14. 我记单词时, 将单词放到具体的句子或语篇的上下文语境中来加深记忆效果。

15. 当我记一个单词时, 通过用这个单词造句来加深记忆与理解。

16. 将单词放入短语、固定搭配或情境中去记忆单词。 
17. 将已学会的单词运用到口语中来加强记忆。

18. 我通过使用关键词的方法来记忆单词。比如我在记 coconut 时, 就联想它是一种水果可以解渴。因此 coconut 与“口渴了拿它”记在一起。“口渴了拿它”就是关键词。

1.2.3.4.5

APPENDIX B

一. Translation

\begin{tabular}{llllllll} 
abandon aboard & \multicolumn{2}{c}{ absolute } & absolutely & balloon bargain & ceremony & edge lane layer \\
loyalty mate muscle normal persist & sulphur & sword & ultimate & vertical run out of
\end{tabular}

二. Paraphrase

sack multiply limitation come to life liter lump hire frog fulfil without doubt discourage couple convince breed surgery resist retreat ridge laundry keep down

\section{ACKNOWLEDGEMENTS}

I am so grateful to all my teachers who have taught me in my study for the knowledge I have obtained.

I also want to express my sincere gratitude to my classmates who gave me valuable suggestions when I encounter difficulties during the work.

I would like to express my thanks to my beloved parents and friends, and my family, for their concern and loving care.

I'll cherish all of this and encourage myself.

\section{REFERENCES}

[1] Alan, Baddeley. (2003). Working memory and language: an overview. Journal of Communication Disorders, 36, $189-208$.

[2] Atkinson, R.C. \& R.M. Shiffrin. (1968). Human memory: a proposed system and its control process. New York: Academic Press.

[3] Carroll, W. D. (2000). Psychology of language. Beijing: Foreign Language Teaching and Research Press.

[4] Carter, Ronald \& McCarthy, Michael. (1990). Vocabulary and language teaching, New York: Longman.

[5] Craik, F. I. M. \& Tulving, E. (1975). Depth of processing and the retention of words in episodic memory. Journal of experimental psychology, 104, 268-294.

[6] Lv Wenpeng. (2001). An investigation into mnemonics for the task of difficult words in an EFL situation. Foreign Language Education, 22, 75-79.

[7] Lawson, M.L. \& D. Hogben. (1998). Learning and recall of foreign-language vocabulary: effects of a keyword strategy for immediate and delayed recall. Learning and Instruction, 8, 179-194.

[8] Ma Guanghui. (1997). A study on the differences of learning strategies between high achievers and low achievers. Foreign Language World, 2, 39-41.

[9] Nation, I.S.P. (1990). Teaching and learning vocabulary. New York: Newbury House.

[10] Oxford, Rebecca. L. (1990). Language learning strategies: What every teacher should know. New York: Newbury House .

[11] O’Malley, J.Michael. \& Chamot, Anna. (1990). Learning strategies in second language acquisition. Cambridge: Cambridge University Press.

[12] Stuart, Luppescu. \& Richard, Day. (1993). Reading, dictionaries and vocabulary learning. Language Learning, 43, $263-265$.

[13] Schmitt, Norbert \& Meara, Paul. (1997). Researching vocabulary through a word knowledge framework: word associations and verbal suffixes. Studies in Second Language Acquisition, 19, 17-36.

[14] Wang Wenyu. (1998). Beliefs, strategies and English vocabulary retention. Foreign Language Teaching and Research, 1, 47-51.

[15] Wu, Jianmin. , Yao, Meilin \& Pang, Hui. (2000). The English vocabulary memorizing strategies of junior middle school students. Journal of Psychological Science, 6, 682-683.

[16] Wen, Qiufang. (1996). On English learning strategies. Shanghai: Shanghai Foreign Language Education Press.

Yiying Wang was born in Linfen, China in 1995. She received her bachelor's degree from Shanxi Normal University, China in 2018.

She is currently a graduate student in the School of Foreign Languages, Shanxi Normal University, Shanxi, China. Her research interest is pragmatics. 